Research Article

\title{
Phytochemical screening, nutritional profile and anti-diabetic effect of ethanolic leaf extract of Cnidoscolus aconitifolius in streptozotocin induce diabetic mice
}

\author{
Debendra Nath Roy*, Nowrin Ferdiousi, Tania Khatun, Md. Ripon Ali Moral
}

Department of Pharmacy, Faculty of Biological Science and Technology, Jessore University of Science and Technology, Jessore-7408, Bangladesh

Received: 04 August 2016 Accepted: 03 September 2016

*Correspondence to:

Debendra Nath Roy,

Email: dn.roy@just.edu.bd

Copyright: () the author(s), publisher and licensee Medip Academy. This is an openaccess article distributed under the terms of the Creative Commons Attribution NonCommercial License, which permits unrestricted noncommercial use, distribution, and reproduction in any medium, provided the original work is properly cited.

\begin{abstract}
Background: Herbal plants for their different medicinal values and formulation has been found to be effective for the treatment of various diseases since ancient period and potency of these plants are largely due to the presence of phytochemicals contained in it. Cnidoscolus aconitifolius is a perennial shrub of the family: euphorbiaceae commonly found in the tropics. This study is aimed at investigating the phytocomponents and hypoglycemic effect of ethanolic leaf extract of Cnidoscolus aconitifolius in streptozotocin induced-diabetic mice.

Methods: Thirty (30) mice with average weight of $23 \mathrm{~g}$ were randomly assigned into five groups of 6 each animal each. Group 1: served as negative control (Non-diabetic) and received normal mice chow and water; Group 2: Served as positive control group and received $10 \mathrm{mg} / \mathrm{kg}$ body weight (bw) of glibenclamide; groups 3, 4 and 5 served as test, and received $100 \mathrm{mg} / \mathrm{kg} \mathrm{bw}$, $150 \mathrm{mg} / \mathrm{kg}$ bw and $200 \mathrm{mg} / \mathrm{kg}$ bw of Cnidoscolus aconitifolius leaf extract respectively orally for 28 days. After one week of acclimatization, diabetes was induced with a single intraperitoneal injection of streptozotocin (STZ) at a dose of $60 \mathrm{mg} / \mathrm{kg}$ bw. Phyto chemicals, phytonutrients and mineral compositions were also determined from the leaf extract of Cnidoscolus aconitifolius.

Results: The phytochemical screening of Cnidoscolus aconitifolius revealed highly abundant levels of alkaloids and flavonoids, with moderate levels of tannins and others. $6.0 \%$ crude protein, $37 \%$ crude fibre, $5.0 \%$ crude fat, $3.0 \%$ ash and $8.1 \%$ muslin were found as the phytonutrients of the extract. The mineral composition of per gram extract showed $13 \mathrm{mg}$ iron, $95 \mathrm{mg}$ phosphorus, $0.03 \mathrm{mg}$ sodium, $89 \mathrm{mg}$ magnesium, $22 \mathrm{mg}$ potassium, $16 \mathrm{mg}$ manganese, and $55 \mathrm{mg}$ calcium. Hypoglycemic effect was investigated in streptozotocin-induced diabetic mice and a dose dependent reduction in blood glucose level was found to have with huge reduction at a dose of $200 \mathrm{mg} / \mathrm{kg}$ from $245.33 \pm 13.01(\mathrm{mg} / \mathrm{dl})$ to $187.03 \pm 7.19(\mathrm{mg} / \mathrm{dl})$ after intrapertitoneal administration $(\mathrm{p}<0.05)$ of extract. Conclusions: Our achieved result revealed the ability of Cnidoscolus aconitifolius to lower blood glucose level and contained remarkable amount of various phyto components as well; hereby suggesting that it could serve as a better therapy for diabetes mellitus and paving way for further investigation to identify the actual bioactive compounds responsible.
\end{abstract}

Keywords: Phytochemicals, Hypoglycemic, Streptozotocin, Diabetic

\section{INTRODUCTION}

It had specified the requirement to know the composition of biologically active botanical substances considered for usage for nutritional and medicinal purposes by World Health Organization (WHO), as such scientific evidence will ensure the use of safe, effective and quality products and practices. ${ }^{1}$ For this reason, it is pertinent to assess the nutritive and electrolyte values of Cnidoscolus aconitifolius (CA) consumed in Bangladesh whose phytomedicinal constituents had been characterized is sometimes known as chaya or spinach tree., ${ }^{2,3}$ The 
potency of a plant is largely due to the presence of phytochemicals contained in different parts of plants and these herbal plants are being increasingly utilized to treat a wide variety of clinical diseases. ${ }^{4}$ Herbs have been used by all cultures throughout history and thus, herbal medicine is the oldest form of health care known to mankind and act as source of medicinal compound continue to play a dominant role in maintenance of human health since antiquities. ${ }^{5}$ The primary benefit of using plant derived-medicine is that they are relatively safer than synthetic alternatives, offering profound therapeutic benefits and affordable treatment. ${ }^{6}$ Many phytochemicals have been identified as components of food and more are still being discovered. ${ }^{7,8}$

Diabetes mellitus is a chronic and progressive disorder characterized by hyperglycemia and metabolic disturbances of carbohydrate, protein, and lipids. ${ }^{9}$ In particular, type 2 diabetes has increased over recent years, in accordance with age, obesity, and smoking. ${ }^{10}$ Diabetes is the world's largest endocrine disease with deranged carbohydrate, fats and protein metabolism. As part of the pathogenesis of type 2 diabetes; skeletal muscle, liver, glucose and adipose tissue become resistant to the hormonal effect of insulin, which in turn lead to decreased insulin-mediated glucose disposal, hepatic glucose overproduction and a marked increase in lipolysis. ${ }^{11}$ There are an estimated 143 million people in the world with diabetes mellitus and this number will probably double by the year $2030 .{ }^{12}$ However, due to the enormous costs of modern treatment for diabetes in developing countries, the use of medicinal plants and their preparation has flourished as an alternative for the control and prevention of the disease. ${ }^{13}$ Natural remedies from medicinal plants are considered to be effective and safe alternative treatment for hyperglycaemia and liver toxicity. There is a growing interest in herbal remedies because of their effectiveness, minimal side effects in clinical experience, and relatively low cost. Herbal drugs or their extracts are prescribed widely, even when their biological active compounds are unknown. ${ }^{14}$ Therefore; studies with plant extracts are useful to know their efficacy and mechanism of action and safety.

The nutritional value of chaya is very attractive when compared with spinach other common vegetable and contained phenols, saponins, cardiac glycosides and Phlobatannin. ${ }^{15-17}$ The plant which is also called spinach tree, has a great potential to alleviate deficits in population of developing countries as it is rich in essential amino acid, vitamin and mineral. ${ }^{18-20}$ High fiber content and antibacterial activities of this plant have been reported. ${ }^{19}$ Apart from the antibacterial activities, the ameliorative effect of Cnidoscolus aconitifolius on anaemia and increased erythrocyte osmotic fragility induced by protein energy malnutrition has been reported. $^{21}$

Although the plant is mainly cultivated as food, it has continued to be an important medicinal plant. Much of its recent spread into new areas may likely be attributed to its medicinal value. A wide variety of claims have been made for its medicinal efficacy as a treatment for numerous ailments ranging from its ability to strengthen fingernails and darken gray hair to cure for alcoholism, insomnia, gout, scorpion stings, brain and vision improvement. $^{22}$ It is a widely distributed annual plant, ranging from temperate to tropical zones, and has a long history of use as both a medicinal and an edible plant. ${ }^{23,24}$ Cnidoscolus aconitifolius is primarily a food plant; it has been used therapeutically for a number of ailments such as diabetes, arteriosclerosis, gallstone and high cholesterol, obesity, acne, kidney stones and eye problems. $^{25-27}$ It is also believed that Cnidoscolus aconitifolius cleans the circulatory system, stimulate lactation, improve eyesight, strengthens nails, improve digestion, and is a diuretic and laxative agent. ${ }^{28}$ Despite these array of uses to which parts of Cnidoscolus aconitifolius are put to, scanty literature is available on its anti-diabetic potential and possible phytochemical(s) portending this effect. Hence, this study therefore aims at scientifically investigate the phytochemical screening, nutritional statuses, and anti-diabetic effect of leaf extract of Cnidoscolus aconitifolius in diabetic mice.

\section{METHODS}

\section{Experimental plants}

Fresh leaves of Cnidoscolus aconitifolius were obtained from a local garden at Rajshahi city in Bangladesh and were correctly identified by the Department of Botany at the University of Rajshahi, Rajshahi -6205 in Bangladesh, with reference number: $\mathrm{CaRg} / \mathrm{RUB} / 019$.

\section{Extraction of plants}

The fresh leaves were air dried and pulverized with electric griending machine into minute pieces weighting 150 g. Ethanolic $(1 / 4, \mathrm{v} / \mathrm{v})$ extraction was carried out with Soxhlet extractor (model no. 3567, Austria). The extract obtained was filtered using Whatman No-1 filter paper. The filtrate was concentrated under reduced pressure in vacuum at $45^{\circ} \mathrm{C}$ using rotator evaporator (Gallen Kamp, UK). The resulting residues were then transferred to a hot oven where they were dried to a constant weight at $45^{\circ} \mathrm{C}$. The extract was stored at $4^{0} \mathrm{C}$.

\section{Experimental design}

Thirty (30) mice with average weight of $23 \mathrm{~g}$ were randomly assigned into five groups of 6 animals each. Group 1: Served as negative control (non-diabetic) and received normal mice chow and water; group 2: Served as positive control group and received $10 \mathrm{mg} / \mathrm{kg}$ body weight (bw) of glibenclamide; group 3, 4, and 5 served as test and received $100 \mathrm{mg} / \mathrm{kg} \mathrm{bw}, 150 \mathrm{mg} / \mathrm{kg}$ bw and 200 $\mathrm{mg} / \mathrm{kg}$ bw of Cnidoscolus aconitifolius leaf extract respectively orally for 28 days. After the extract administration, animals were anaesthetized using $25 \%$ 
urethane (ethyl carbamate) at the dose of $0.6 \mathrm{ml} / 100 \mathrm{~g}$ intraperitioneally; blood samples were collected for laboratory determination of blood glucose level.

\section{Induction of diabetics in mice}

After one week of acclimatization, diabetes was induced with a single intraperitioneal injection of streptozotocin (STZ) at a dose of $60 \mathrm{mg} / \mathrm{kg}$ body weight (bw), after 18 hours fast according to the method. The streptozotocin (STZ) was freshly dissolved in citrate buffer $(0.01 \mathrm{M}, \mathrm{pH}$ 4.5). The injection volume prepared to contain 1.0 $\mathrm{mL} / \mathrm{kg}$. After 5 days, blood glucose levels were measure and the animals with a concentration of more than 230 $\mathrm{mg} / \mathrm{dl}$ were classified as diabetic.

\section{Phytochemical screening}

Preliminary phytochemical analyses of the extracts were performed, seeking to highlight the major groups of secondary metabolites. It was evaluated for the presence of alkaloids, anthocyanin's, coumarins, anthracene derivatives, flavonoids, lignans, mono, and diterpenes, napthoquinones, saponins, steroids and terpenoids.

\section{Test for alkaloids}

$0.5 \mathrm{~g}$ of the extract was stirred with an adequate amount of aqueous hydrochloric acid and filtered. $1 \mathrm{ml}$ of the filtrate was treated with few drops of Mayer's reagent and a second $1 \mathrm{ml}$ portion was treated similarly with Dragendreffs reagent. Precipitation of these reagents was taken as preliminary evidence for the presence of alkaloid in the extract. The appearance of orange or dark coloured spot against a pale yellow background confirmed the presence of alkaloids.

\section{Test for tannins}

$0.5 \mathrm{~g}$ of the extract was stirred with $20 \mathrm{ml}$ of distilled water, filtered and ferric chloride added to the filtrate. A blue- black, green or blue green precipitate indicated the presence of tannins.

\section{Test for phlobatannins}

$2 \mathrm{mg}$ of the extract was boiled with 1 percent (1\%) aqueous hydrochloric acid. Deposition of a red precipitate shows the presence of phlobatannins.

\section{Test for saponins}

$0.5 \mathrm{~g}$ of the extract was added to $5 \%$ sodium carbonate (Na2CO3).Fehling's solution also added and boiled for about 2 minutes. The presence of brown precipate was taken as a positive test for saponins.

\section{Test for flavonoids}

$5 \mathrm{ml}$ of the extract solution was added to $2 \mathrm{ml}$ of sodium hydroxide. Dilute sulphuric acid was then added to confirm. A yellow colour which turned creamy on addition of dilute sulphuric acid, confirms the presence of flavonoids.

\section{Test for anthraquinones}

Bomtrager's test was used for the detection of anthraquinones. $0.5 \mathrm{~g}$ of the extract was mixed with $10 \mathrm{ml}$ benzene, filtered and $5 \mathrm{ml}$ of $10 \%$ ammonia solution added to the filtrate. The mixture was shaken and the presence of a pink -red colour in ammonical phase indicated the presence of free anthraquinones while the presence of violet colour in the lower phase indicates the presence of combined anthraquinones.

\section{Test for terpenes}

To $2 \mathrm{ml}$ of the extract solution, a few drops of glacial acetic acid were added followed by a drop of concentrated sulphuric acid. A red colour indicates the presence of terpenes.

\section{Test for cardiac glycoside}

$0.5 \mathrm{~g}$ of the extracts was dissolved in $2 \mathrm{ml}$ of chloroform and concentrated sulphuric acid was carefully added to form a lower layer. A reddish brown colour at the interphase indicated the presence of steroidal ring of a glycone portion of cardiac glycoside.

\section{Test for phytonutrients}

\section{Determination of crude protein}

$0.5 \mathrm{~g}$ of the extract was mixed with $10 \mathrm{ml}$ of $0.02 \mathrm{~mol}$ $\mathrm{H}_{2} \mathrm{SO}_{4}$ in a digestion flask. Selenium catalyst was added to it before heating under a fume cupboard until a clear solution was obtained. The digest was diluted in a volumetric flask \& used for analysis. $10 \mathrm{ml}$ of the digest was mixed with equal volume of $45 \% \mathrm{NaOH}$ solution in Kyelkdahl distillation apparatus, the mixture was distilled into $10 \mathrm{ml}$ of $4 \%$ basic acid containing 3 drops of mixed indicator (methyl red). A total of $50 \mathrm{ml}$ distillates was collected and titrated against 0.02 EDTA from green to a deep end point. A reagent was also digested, distilled and titrated. The content and hence protein content was calculated using the following formula.

$\%$ Protein $=\% \mathrm{~N} 2 \times 6.25$
$\% \mathrm{~N} 2=[100 / \mathrm{N} \times \mathrm{W} \times 14 / 100 \times \mathrm{Vt} / \mathrm{Va}] \mathrm{T}-\mathrm{B}$

Where;

$\mathrm{W}=$ Weight of extract $(0.5 \mathrm{~g})$

$\mathrm{N}=$ Normality of titrate $(0.02 \mathrm{~N} \mathrm{H} 2 \mathrm{SO} 4)$

$\mathrm{Vt}=$ Total digest volume $(100 \mathrm{ml})$

$\mathrm{Va}=$ Volume of digest analyzed $(10 \mathrm{~m} / \mathrm{s})$

$\mathrm{T}=$ Sample

$\mathrm{B}=$ Blank litre value

\section{Ash determination}

This was done by the furnaces incineration gravimetric method. $0.5 \mathrm{~g}$ of the extract was measured into a previously weighed porcelium crucible. The sample was burnt to ashes in a muffle furnace at $550^{\circ} \mathrm{C}$. The ashes was cooled in a desiccator and weighed. The weight of ashes 
obtained was calculated by difference and expressed as a percentage of the weight of sample analysed below:

Ash $=100 / 1 \times w 2-w / w t$ of sample

Where;

$\mathrm{W} 1$ = weight of empty crucible

$\mathrm{W} 2$ = weight of crucible + ash

\section{Determination of crude fat}

The solvent extraction gravimetric method was used. 0.5 $\mathrm{g}$ of the extract was wrapped in a porous paper (Whitman filter paper) and put in a thrimble. The thrimble now put in a soxhlet reflux and mounted into a weighted extract flask containing $200 \mathrm{ml}$ of petroleum ether. Soon the sample in the thrimble was covered with the solvent, which extract the oil (fat). The sample remained in contact with the solvent until the reflux flask filled up and siphoned over, carrying its oil extract down to the boiling flask. The process went on repeatedly for 4 hour before the defatted sample was removed, the solvent recovered and the oil extract were left in the flask. The flask containing the oil solvent was dried in the oven at $60^{\circ} \mathrm{C}$ for $30 \mathrm{mins}$ (to remove any residual solvent). It was cooled in desiccators and weighed. By difference, the weight of oil (fat) extract was determined and expressed as a percentage of the weight of sample analysed and given by the expression below:

$\%$ of fat $=\mathrm{W} 2-\mathrm{W} 1 / \mathrm{Wt}$. of sample $\times 100 / 1$

Where;

$\mathrm{W} 1$ =weight of empty extraction flask

$\mathrm{W} 2=$ weight of flask + (fat) extract

\section{Mineral analysis}

The determination of endogenous minerals was done in Soil Research Centre, Rajshahi-6205, in Bangladesh by AOAC method. ${ }^{29}$

\section{Determination of hypoglycemic properties}

After two weeks period of acclimatization, 30 mice with an average weight of $23 \mathrm{~g}$ were randomly divided into five groups of six mice in each. Group-1 (non-diabetic control) received oral administration of $1 \mathrm{ml}$ of water, while diabetes was induced in the remaining groups by intraperitoneal injection of $60 \mathrm{mg} / \mathrm{kg}$ of streptozotocin (diabetogenic agent) after starving the mice overnight. Before and after inducing diabetes, the blood glucose level of the mice was measured using single touch Accuchek glucometer and only established diabetic mice after 72 hours were selected for treatment. Group- 2 received oral administration $10 \mathrm{mg} / \mathrm{kg}$ of glibenclamide (known anti diabetic agent), while group- 3, group- 4, and group5 were orally administered with $100 \mathrm{mg} / \mathrm{kg}, 150 \mathrm{mg} / \mathrm{kg}$ and $200 \mathrm{mg} / \mathrm{kg}$ of the ethanolic extract of Cnidoscolus acotinifolius respectively for 28 days.

\section{Statistical analysis}

The results were expressed as mean of 6 replicates \pm standard error of mean (SEM) and were analysed using Statistical Package for Social Sciences (SPSS) version 20.0. One way analysis of variance (ANOVA) was performed to test the effect of each dose on the parameter under investigation at $95 \%$ level of confidence. Values were considered statistically significant at $(\mathrm{p}<0.05)^{7}$

\section{RESULTS}

Phyto constituents of ethanolic leaf extracts of Cnidoscolus aconitifolius are as shown in following Table 1.

From the Table 1, the phytonutrient screening of the extract shows the presence $6.0 \%$ crude protein, $37 \%$ crude fibre, $5.0 \%$ crude fat, $3.0 \%$ ash and $8.1 \%$ muslin. Phytomineral screening study was carried out and the result obtained from the ethanolic extracts of Cnidoscolus aconitifolius were $13 \mathrm{mg}$ iron, $95 \mathrm{mg}$ phosphorus, 0.03 mg sodium, $89 \mathrm{mg}$ magnesium, $22 \mathrm{mg}$ potassium, $16 \mathrm{mg}$ manganese, and $55 \mathrm{mg}$ calcium also presented in Table 1.

A statistically significant $(\mathrm{p}<0.05)$ increase was observed in the fasting blood glucose level of negative control (group-1) animals after administration of streptozotocin as shown in following Table 2 .

This is also recorded in case of group-2 $(10 \mathrm{mg} / \mathrm{kg}$ Glibenclamide), group-3 (100 mg/kg extract), group-4 $(150 \mathrm{mg} / \mathrm{kg}$ extract) and group-5 (200 mg/kg extract) after induction of diabetes. However, significant $(\mathrm{p}<0.05)$ reduction in blood glucose level was observed for each group after treatment with ethanolic leaf extract of Cnidoscolus aconitifolius especially when at the high dose of the extract was administered. Therefore, a dose dependent reduction in blood glucose level was found to have with a maximum reduction at a dose of $200 \mathrm{mg} / \mathrm{kg}$ from $245.33 \pm 13.01(\mathrm{mg} / \mathrm{dl})$ to $187.03 \pm 7.19(\mathrm{mg} / \mathrm{dl})$. Thus, the high dose of the ethanolic extract administered showed even a better therapeutic effect compared to the standard ant diabetic drug (Glibenclamide) administered. However, the presence of dietary fibres in the phytonutrient screening of the extract might be implicated for the possible anti-diabetic potential of this extract. 
Table 1: Phyto components screening test of ethanolic leaf extract of Cnidoscolus aconitifolius.

\begin{tabular}{|lllllll|}
\hline Phytochemicals & Inference & Phytonutrients & Quantity (\%) & Phyto minerals & Quantity (mg/gm) \\
\hline Alkaloids & ++ & Crude protein & 6.0 & Iron & 13 \\
\hline Tannins & + & Crude fibre & 37 & Phosphorus & 95 \\
\hline Phlobatannins & + & Crude fat & 5.0 & Sodium & 0.03 \\
\hline Saponins & + & Ash & 3.0 & Magnesium & 89 & 22 \\
\hline Flavonoids & ++ & Muslin & 8.1 & Potassium & Manganese & 16 \\
\hline Free anthraquinones & + & & & Calcium & 55 \\
\hline Combined anthraquinones & + & & & & \\
\hline Terpenes & + & + & & & & \\
\hline Cardiac glycoside & + & & & & \\
\hline Cyanogenetic glycoside & + & &
\end{tabular}

+: Moderately abundant; ++: Highly abundant.

Table 2: Mean fasting blood sugar level before and after extract administration in mice.

\begin{tabular}{|lllll|}
\hline & & \multicolumn{3}{c|}{ Fasting blood glucose level (mg/dl) } \\
\cline { 2 - 5 } Groups & Treatments & $\begin{array}{l}\text { Before STZ } \\
\text { induction }\end{array}$ & $\begin{array}{l}\text { After STZ } \\
\text { induction }\end{array}$ & $\begin{array}{l}\text { After drug } \\
\text { treatment }\end{array}$ \\
\hline Group 1 (negative control) & Distilled water & $71.23 \pm 2.81$ & $242.69 \pm 8.99^{*}$ & $242.01 \pm 8.25^{*}$ \\
\hline Group 2 (positive control) & $10 \mathrm{mg} / \mathrm{kg} \mathrm{bw} \mathrm{Glibenclamide}$ & $68.67 \pm 2.04$ & $249.37 \pm 16.83^{*}$ & $209.39 \pm 11.83^{*}$ \\
\hline Group 3 & $100 \mathrm{mg} / \mathrm{kg}$ of leaf extract & $71.10 \pm 3.01$ & $239.93 \pm 9.33^{*}$ & $218.12 \pm 8.14^{*}$ \\
\hline Group 4 & $150 \mathrm{mg} / \mathrm{kg}$ of leaf extract & $61.13 \pm 1.23$ & $245.10 \pm 9.75^{*}$ & $210.15 \pm 10.44^{*}$ \\
\hline Group 5 & $200 \mathrm{mg} / \mathrm{kg}$ of leaf extract & $73.49 \pm 2.89$ & $245.33 \pm 13.01^{*}$ & $187.03 \pm 7.19^{*}$ \\
\hline
\end{tabular}

Values are expressed as mean \pm SEM; $n=5 ; *=$ Significant at $\mathrm{p}$ level less than 0.05 compared with glucose level before streptozotocin induction.

\section{DISCUSSION}

The results of the present study show that, the ethanolic extract of $C$. aconitifolius in hold possible strong antioxidant activity, owing to the high presence of flavonoids which are known antioxidants. Flavonoids in plants are known for their scavenging ability as a result of the presence of hydroxyl groups present in them. Other phytochemicals such as alkaloids, tannins, phlobatannins, saponins, free anthraquinones, combined anthraquinones, terpenes, cardiac glycoside and cyanogenetic glycoside were also shown to have in $\mathrm{C}$. aconitifolius. The presence of muslin in the ethanolic leaf extract of Cnidoscolus aconitifolius revealed the possible use of this herbal plant in the arrest of bleeding especially in aneurysms or intracranial vessels at risk of bleeding. Moreover, muslin is used as gauze to reinforce an artery and help prevent rupture. In emergency medicine, muslin may be used in the manufacture of bandage and tourniquets. ${ }^{30}$

The dietary fibers or "roughages" revealed in the study, might help to prevent constipation by increasing stool weight and transit time, hence reducing the risk of disease and disorders such as diverticular disease or hemorrhoids and may also have a protective response on colon cancer. ${ }^{31}$ The elevated amounts of phosphorus, calcium, magnesium obtained from the phytomineral screening of the extract is in consonance with the report of that the three minerals- calcium, phosphorus and magnesium accounts for about $98 \%$ of the body's mineral content by weight, especially in infants. ${ }^{32}$

The hypoglycemic strength exhibited by this extract may be due to the presence of tannins and saponins. These compounds have since shown to have immense significance as anti hypercholesterol, hypotensive and cardiac depressant properties and as blood glucose reducing agents as well. ${ }^{33}$ Although, $C$. aconitifolius serves as an ideal anti diabetic medication at different doses but at a high dose of its leaf extract could be used for better therapeutic effect. However, dietary fibers may show digestion and absorption of carbohydrates and hence lower the rise in blood glucose. The possible mechanism of hypoglycemic action of $C$. aconitifolius is due to the increased glucose uptake in liver cells because it markedly lowers the blood glucose levels in streptozotocin induced diabetic mice.

\section{CONCLUSION}

The use of $C$. aconitifolius may contribute significantly in overcoming protein deficiency in the developing countries where good quality proteins from animal sources are either unavailable or even unacceptable for religious beliefs. However, this study shows the ability of $C$. aconitifolius to lower blood glucose level; thereby suggesting that it could serve as a better therapy for diabetes mellitus and paving way for further investigation 
to identify the actual bioactive compounds responsible. Moreover, we have got novel information on the presence of muslin an active phytonutrient, used in the arrest of bleeding in aneurysms. This might lead to the development of new excellent alternative natural remedy in cardiovascular studies. Therefore, there is need to assess the nutrient potentials of $C$. aconitifolius as they can help in the fight against micro-nutrient malnutrition. So, analysis of the nutrient values and mineral analysis of this medicinal plant is the focus of this study.

\section{ACKNOWLEDGEMENTS}

Authors would like to thanks to department of Botany, University of Rajshahi, Bangladesh for identifying this medicinal plant in our research work. Authors would like to extend their gratitude to the Soil Resource Development Institute, Regional Research centre at Rajshahi in Bangladesh for their cordial support in mineral analysis and the authors would also like to extend their gratitude to the Department of Pharmacy, Jessore University of Science and Technology, Bangladesh for providing necessary facilities throughout our research work.

\section{Funding: No funding sources}

Conflict of interest: None declared

Ethical approval: The study was conducted following the general principles of World Medical Association (WMA) declarations of Helsinki. This research work is logistically supported by the department of Pharmacy, Jessore University of Science and Technology, Jessore7408 in Bangladesh. No human subjects were involved in this study and we didn't use any hazardous agents, therefore, need not to take any further approval from institutional ethics committee

\section{REFERENCES}

1. National policy on traditional medicine and regulation of herbal medicines report of a WHO Global Survey, 2012.

2. Awoyinka AO, Balogun IO, Ogunnowo AA. Phytochemical screening and in vitro bioactivity of Cnidoscolus aconitifolius Euphorbiaceae. J Med Plant Res. 2007;3:63-5.

3. Iwuji SC, Nwafor A, Egwurugwu J, Ejeta K, Akpan U. Comparative characterization of the phytomedicinal constituents of cnidoscolus aconitifolius leaf extracts. American J Pharm Tech. 2013;3(1):779-84.

4. Joseph M, Ugochukwu U, Eze N, Ambrose O. Effect of the dry aqueous leaf extract of cnidoscolus aconitifolius on blood alcohol clearance in rabbits. Journal of Natural Sciences Research. 2013;3(5):916.

5. Oyagbemi AA, Odetola AA. Hepatoprotective effects of ethanolic extract of Cnidoscolus aconitifolius on paracetamol-induced hepatic damage in rats. Pakistan Journal of Biological Science. 2010;13(4):164-9.
6. Sakpa, Lucky C, Nwachi U, Edward O. Histological effects of aqueous leaf extract of Chaya (Cnidoscolus Aconitifoliu) on the testes and epididymis of adult Wistar rats. J Biomed Sci. 2014;13 (1):120-8.

7. Adeniyi OA, Adebiyi OO, Ilesanmi OR, Raji Y. Sedative effect of hydroalcoholic leaf extracts of Cnidoscolus Aconitifolius. Intl J Appl Res Nat Prod. 2012:5(1);1-6.

8. Okokuma EI. Effects of alcoholic extract of cnidoscolus aconitifolius on bone marrow biopsy in adult male wistar rats. Basic Sciences of Medicine. 2012;1(1):6-8.

9. Expert committee on the diagnosis and classification of diabetes mellitus. Report of the expert committee on the diagnosis and classification of diabetes mellitus. Diabetes Care. 2003;26:S5-20.

10. Chung HR, Pérez-Escamilla R. Risk factors of type 2 diabetes among Korean adults: The 2001 Korean national health and nutrition examination survey. Nutr Res Pract. 2009;3:286-94.

11. Nanu R, Raghuveer I, Chitme HR, Chandra R. Antidiabetic activity of Nyctanthes arbortristis, Pharmacognosy Magazine. 2008;16:335-40.

12. Boyle JP, Honeycutt AA, Narayan KM, Hoerger TJ, Geiss LS, Chen H, et al. Projection of diabetes burden through 2050: impact of changing demography and disease prevalence in the U.S. Diabetes Care. 2001;24(11):1936-40.

13. Luo J, Fort DM, Carlson TJ, Noamesi BK, NiiAmon-Kotei D, King SR, et al. Cryptolepis sanguinolenta: an ethnobotanical approach to drug discovery and the isolation of a potentially useful new antihyperglycaemic agent. Diabet Med. 1998;15(5):367-74.

14. Gupta RK, Kesari AN, Murthy PS, Chandra R, Tandon V, Watal G. Hypoglycemic and antidiabetic effect of ethanolic extract of leaves of Annona squamosa L. in experimental animals," Journal of Ethnopharmacology. 2005;99(1):75-81.

15. Nwaoguikpe, Nwazue R. The effect of extract of bitter leaf Vernonia amygdalina on blood glucose levels of diabetic rats. Int $\mathrm{J}$ Biol Chem Sci. 2010;4(3):721-9.

16. Mbaya JC, Bornice F, Nagati K. Guidelines for the management of NIDDM in Africa. In a consensus Document, NOVO, HOR disk A/S Voluliagment, Greece; 1996:1-37.

17. Amos AF, McCarty DJ. The rising global burden of Diabetic mellitus and its complication, estimates and projection for the year, 2010, Diabetic Medicare. 1997;14:57-9.

18. Lensen S. Mechanism of Alloxan and Streptozocininduced diabetes, Diabetologia. 2008;51(2):216-26.

19. Kuti JO, Kuti HO. Proximate composition and minimal content of two edible species of Cnidoscolus tree spinach. Plant Foods Hum Nutr. 1999;53(4):27583.

20. Adebiyi OA, Adebiyi OO, Ilesanmi OR, Raji Y. Sedative effect of hydroalcholic leaf extracts of 
Cnidoscolous acontifolius. Intl $\mathbf{J}$ of Appl Res Nat Prod. 2012;5(1):1-6.

21. Awoyinka AO, Balogun IO, Ogunmowo AA. Phytochemical screening and in vitro bioactivity of Cnidoscolus aconitifolius Euphorbiaceae. Journal of Medicinal Plants Research. 2007;19130:63-5.

22. Jensen SA, Chaya. The Mayan miracle plant. J Food Sci. 1997;51:234-44.

23. Atuahene CC, Poku-Prempeh B, Twun G. The nutritive values of chaya leaf meal Cnidoscolus aconitifolius studies with broilers chickens. Anim Feed Sci Technol. 1999;77:163-72.

24. Nebel S, Heinrich M. Chòrta TA. A comparative ethnobotanicallinguistic study of wild food plants in a Graecanic area in Calabria Southern Italy. Econ Bot. 2009;63(1):78-92.

25. Samuel IW, Wafor A. Antihyperglyceamic efficacy of Cnidoscolus aconitifolius compared with glibenclamide in Alloxan-induced Diabetic Wista rats. Intl Res J Med Sci. 2014;2(3):1-4.

26. Kuti JO, Torres ES. Potential nutritional and health benefits of Tree spinach Cnidoscolus chayamansa.
Progress in new crops, American society of Horticulture Science Press; 1996.

27. Rowe L. Plant guards secret of good health. Valley Morning Star. 1994;4:12.

28. Oyagbemi AA, Odetola AA, Azeez OI. Ameliorative effects of Cnidoscolus aconitifolius on anaemia and osmotic fragility induced by protein energy malnutrition. African Journal of Biotechnology. 2008;7(11):1721-6.

29. AOAC. Official methods of analysis, $13^{\text {th }}$ Edition. Association of official analytical chemists, Washington, DC; 1995.

30. Hartmann M, Wildemann B. Progressive visual loss due to a muslinoma - report of a case and review of the literature. Eur J Neurol. 2003;10(2):153-8.

31. De Vries J. On defining dietary fibre Proc of the Nutrition Society. 2003;62:37-43.

32. Nutrition: what every parent needs to know, american academy of paediatrics; 2011.

33. Trease GE, Evans WC. Pharmacology $11^{\text {th }}$ Edn. Bailliere Tindall Ltd., London. 1989;60-75.

Cite this article as: Roy DN, Ferdiousi N, Khatun T, Morol MRA. Phytochemical screening, nutritional profile and anti-diabetic effect of ethanolic leaf extract of Cnidoscolus aconitifolius in streptozotocin induce diabetic mice. Int J Basic Clin Pharmacol 2016;5:2244-50. 